Utah State University

DigitalCommons@USU

Green Canyon Environmental Research Area, Logan Utah

Quinney Natural Resources Research Library, S.J. and Jessie E.

2006

\title{
Terpenes and Carbohydrate Source Influence Rumen Fermentation, Digestibility, Intake, and Preference in Sheep
}

\author{
J. J. Villalba \\ F. D. Provenza \\ K. C. Olson
}

Follow this and additional works at: https://digitalcommons.usu.edu/grcanyon

Part of the Animal Sciences Commons, Biology Commons, Environmental Monitoring Commons, Natural Resources and Conservation Commons, Plant Sciences Commons, Population Biology Commons, Soil Science Commons, and the Terrestrial and Aquatic Ecology Commons

\section{Recommended Citation}

Villalba, J. J.; Provenza, F. D.; Olson, K. C. 2006. Terpenes and Carbohydrate Source Influence Rumen Fermentation, Digestibility, Intake, and Preference in Sheep. Journal of Animal Science 84(9): 2463-2473.

This Article is brought to you for free and open access by the Quinney Natural Resources Research Library, S.J. and Jessie E. at DigitalCommons@USU. It has been accepted for inclusion in Green Canyon Environmental Research Area, Logan Utah by an authorized administrator of DigitalCommons@USU. For more information, please contact digitalcommons@usu.edu.

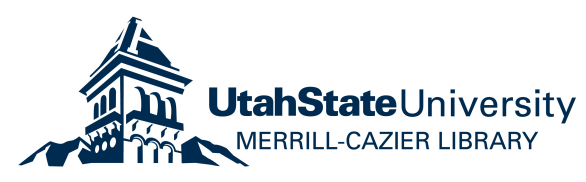




\section{Utah State University}

From the SelectedWorks of Frederick D Provenza

2006

Terpenes and carbohydrate source influence rumen fermentation, digestibility, intake, and preference in sheep

Frederick D Provenza 


\title{
Terpenes and carbohydrate source influence rumen fermentation, digestibility, intake, and preference in sheep ${ }^{1,2}$
}

\author{
J. J. Villalba,*3 F. D. Provenza,* and K. C. Olson $\dagger$ \\ *Department of Forest, Range and Wildlife Sciences; $†$ Department of Animal, Dairy and Veterinary Sciences, \\ Utah State University, Logan 84322-5230
}

\begin{abstract}
We hypothesized that toxins and nutrients in foods interact to influence foraging behavior by herbivores. Based on this hypothesis we predicted that 1) terpenes in big sagebrush (Artemisia tridentata) influence intake and preference in sheep for diets varying in sources of nonstructural (barley grain) and structural (sugar beet pulp) carbohydrates, and 2) these effects are due to the differential effects of terpenes on fermentation products and apparent digestibility of each class of carbohydrates. Lambs were fed 2 isoenergetic and isonitrogenous diets with varying proportions of the same ingredients (beet pulp- and barley grainbased diet) or offered a choice between the 2 diets; all feeds were fed without and with terpenes, in consecutive periods. We also compared intake and preference of the beet pulp- and barley-based diets before and after the lambs ate a meal of sagebrush. Finally, we assessed the effect of terpenes on ruminal variables and in vivo digestibility. Lambs ate less when fed beet pulp or when they were offered a choice of diets with terpenes $(P<$ 0.001 ), and intake of the beet pulp-based diet was the most affected $(P<0.05)$. Lambs preferred the beet pulp-
\end{abstract}

to the grain-based diet with terpenes, but their preference reversed when terpenes were removed from the diets $(P<0.05)$. When lambs were offered both diets, intake and preference did not differ $(P>0.20)$ before eating sagebrush, but they preferred the beet pulpbased diet after eating sagebrush $(P<0.05)$. Intake of sagebrush did not differ among groups consuming the test diets $(P=0.21)$. Addition of terpenes to both diets increased the digestibility of $\mathrm{DM}, \mathrm{NDF}$, and $\mathrm{ADF}$ and decreased concentrations of total VFA and acetate $(P$ $<0.05)$. Terpenes also depressed butyrate concentration in the barley-based diet $(P<0.05)$. Propionate concentrations were not affected by terpenes in either feed $(P=0.63)$. In summary, the predominant type of feed ingredient (beet pulp, grain) ingested with terpenes influenced fermentation products, intake, and preference in lambs. The source of energy from supplements, or other plants in the diet, is likely to influence intake and preference for sagebrush in sheep foraging on rangelands. Moreover, ingesting terpenes from sagebrush may also influence intake and preference for other plant species or supplements.

Key words: Artemisia tridentata, digestibility, food preference, intake, in vivo, terpene

(C2006 American Society of Animal Science. All rights reserved.

J. Anim. Sci. 2006. 84:2463-2473 doi:10.2527/jas.2005-716

\section{INTRODUCTION}

Big sagebrush (Artemisia tridentata) occurs on millions of hectares of rangeland in the western United States. Though sagebrush is an important forage for

\footnotetext{
${ }^{1}$ This research was supported by grants from the Utah Agricultural Experiment Station and the Initiative for the Future of Agriculture and Food Systems, USDA (Agreement No. 2001-52103-11215). This paper is published with the approval of the director, Utah Agricultural Experiment Station, and Utah State University, as journal paper number 7754 .

${ }^{2}$ We thank L. Lisonbee for technical support.

${ }^{3}$ Corresponding author: villalba@cc.usu.edu

Received December 12, 2005.

Accepted April 29, 2006.
}

wildlife and livestock (Welch, 1983), terpenes can limit its nutritional value (Dziba et al., 2006). The antibacterial effects of terpenes adversely affect rumen fermentation and DM digestibility (Nagy and Tengerdy, 1968), and they retard in vitro fermentation of cellulose and reduce production of VFA (Nagy et al., 1964). Thus, the digestibility of sagebrush and other plants consumed with sagebrush that require extensive microbial degradation of cell walls to yield energy may be affected more by terpenes than plants high in readily fermentable cell solubles.

Herbivores foraging on plants with a diverse array of toxins consume a variety of foods that contain different toxins apparently to avoid overloading individual detoxification pathways with a single toxin (Freeland and Janzen, 1974). Additionally, foods with different nutri- 
tional constituents (fiber and cell solubles) may lead to greater intake or tolerance for toxins that occur in shrubs such as sagebrush. We hypothesized toxins and the nutritional characteristics of feeds interact to influence intake and preference by herbivores. Based on this hypothesis, we predicted 1) terpenes influence intake and preference in sheep for isonitrogenous and isoenergetic diets that vary in concentrations of nonstructural and structural carbohydrates, and 2) these differences are due to the selective effects of terpenes on fermentation products and apparent digestibility.

\section{MATERIALS AND METHODS}

The project was conducted under a research protocol approved by an Institutional Animal Care and Use Committee, Utah State University, Logan.

The study was conducted at the Green Canyon Ecology Center, located at Utah State University in Logan. We determined 1) how terpenes or a terpene-containing plant (big sagebrush) influence intake and preference in lambs for 2 isoenergetic and isonitrogenous diets based on structural (beet pulp) or nonstructural (barley grain) carbohydrates, and 2) the effect of terpenes on fermentation products and apparent digestibility when lambs consume these diets.

\section{Influence of Terpenes on Intake and Preference for Diets of Different Composition}

We used 24 lambs (commercial crossbreds of both sexes, 4 to 5 mo of age) that were individually penned with free access to mineral blocks and fresh water. Lambs (37 $\pm 0.8 \mathrm{~kg}$ of initial BW) were randomly assigned to 3 groups (8 lambs/group). Before exposure to the experimental diets, lambs were given an adjustment period of $2 \mathrm{wk}$, during which we gave them 450 $\mathrm{g}$ of rolled barley grain.lamb $\mathrm{b}^{-1} \cdot \mathrm{d}^{-1}$ and free access to alfalfa pellets. After the 2 -wk adjustment period, at 0800 each morning, lambs received, ad libitum, a beet pulp-based diet (group 1; Table 1), a barley grain-based diet (group 2; Table 1), or a choice of each diet (group 3 ) for $4 \mathrm{~h}$. Intake of the diets was recorded, and no other food was offered until the next day. The procedure was repeated for $14 \mathrm{~d}$. Lambs were familiarized with the procedures for $4 \mathrm{~d}$, and data were recorded for the next $10 \mathrm{~d}$.

After this 14-d period, the procedure was as described before, but terpenes (camphor, 1,8-cineole, methacrolein, and p-cymene; Sigma Chemical Co., St. Louis, MO) were added to the diets (Table 1) at the same relative concentrations found in big sagebrush (Personius et al., 1987; K. Launchbaugh, University of Idaho, Moscow, ID, personal communication); i.e., $1.82 \%$ camphor, $1.1 \%$ 1,8-cineole, $0.12 \%$ methacrolein, and $0.06 \%$ p-cymene (as-is basis), which were dissolved in $4 \%$ vegetable oil and then mixed with the rest of the feed ingredients on a daily basis. Previous studies showed that these terpenes adversely influence intake and diet preference
Table 1. Ingredients and composition of the experimental diets

\begin{tabular}{|c|c|c|}
\hline Item & $\begin{array}{c}\text { Beet } \\
\text { pulp-based }\end{array}$ & Barley-based \\
\hline \multicolumn{3}{|l|}{ Control diet } \\
\hline Ingredient $^{1}$ & \multicolumn{2}{|c|}{ — g/kg, as-fed basis } \\
\hline Beet pulp & 63.0 & 6.0 \\
\hline Barley grain & 6.0 & 55.0 \\
\hline Grape pomace & 6.0 & 15.0 \\
\hline Alfalfa hay & 5.0 & 7.0 \\
\hline Soybean meal & 16.0 & 13.0 \\
\hline Vegetable oil & 4.0 & 4.0 \\
\hline \multicolumn{3}{|c|}{ Composition of the complete diet } \\
\hline $\mathrm{DE},{ }^{2} \mathrm{Mcal} / \mathrm{kg}$ & 3.48 & 3.48 \\
\hline $\mathrm{CP}, 3 \%$ & $17.4 \pm 0.2$ & $17.2 \pm 0.2$ \\
\hline $\mathrm{NDF},{ }^{4} \%$ & $33.6 \pm 0.4$ & $26.4 \pm 0.9$ \\
\hline $\mathrm{ADF}, 4 \%$ & $22.4 \pm 0.1$ & $18.6 \pm 0.8$ \\
\hline Hemicellulose, ${ }^{5} \%$ & $11.3 \pm 0.4$ & $7.8 \pm 0.8$ \\
\hline \multicolumn{3}{|l|}{ Terpene diets } \\
\hline Ingredient $^{1}$ & \multicolumn{2}{|c|}{ - $\mathrm{g} / \mathrm{kg}$, as-fed basis } \\
\hline Beet pulp & 65.0 & 8.0 \\
\hline Barley grain & 6.1 & 55.0 \\
\hline Grape pomace & 1.9 & 10.4 \\
\hline Alfalfa hay & 3.9 & 6.8 \\
\hline Soybean meal & 16.0 & 12.7 \\
\hline Vegetable oil & 4.0 & 4.0 \\
\hline \multirow{2}{*}{\multicolumn{3}{|c|}{$\begin{array}{l}\text { Terpenes } \\
\text { Composition of complete diet }\end{array}$}} \\
\hline & & \\
\hline $\mathrm{DE},{ }^{2} \mathrm{Mcal} / \mathrm{kg}$ & 3.48 & 3.48 \\
\hline $\mathrm{CP}, 3 \%$ & $17.0 \pm 0.1$ & $18.0 \pm 0.2$ \\
\hline $\mathrm{NDF}, 4 \%$ & $31.9 \pm 0.4$ & $24.5 \pm 0.5$ \\
\hline $\mathrm{ADF}, 4 \%$ & $20.8 \pm 0.3$ & $16.5 \pm 0.6$ \\
\hline Hemicellulose, ${ }^{5} \%$ & $11.1 \pm 0.4$ & $8.0 \pm 0.6$ \\
\hline
\end{tabular}

${ }^{1}$ All ingredients were ground to a particle size of 2 to $4 \mathrm{~mm}$.

${ }^{2}$ Calculated values of DE were based on values obtained from NRC (1985).

${ }^{3}$ Nitrogen was determined by Kjeldahl method (AOAC, 1990); CP was calculated as $\mathrm{N} \times 6.25$.

${ }^{4} \mathrm{NDF}$ and ADF were determined according to Goering and Van Soest (1970).

${ }^{5} \mathrm{NDF}-\mathrm{ADF}$.

(Villalba et al., 2002b; Villalba and Provenza, 2005; Dziba et al., 2006). Lambs weighed $38 \pm 0.9 \mathrm{~kg}$ after exposure to the terpene-containing diets.

After exposure to terpenes, the procedure was as described before, but terpenes were removed from the diets. We conducted this last experiment to determine if intake and preference for the diets returned to the baseline values obtained before adding terpenes to the diets. The procedure was repeated for $6 \mathrm{~d}$.

\section{Influence of Sagebrush on Intake and Preference for Diets of Different Composition}

Mountain big sagebrush [Artemisia tridentata Nutt. subsp. Vaseyana (Rydb.) Beetle] was hand-harvested during September 2002 from the foothills near Avon, approximately $20 \mathrm{~km}$ south of Logan, in northern Utah at $41.6^{\circ} \mathrm{N}, 111.8^{\circ} \mathrm{W}$. The current season's leaves and twigs of sagebrush were clipped, placed in woven, polyethylene feed sacks, and frozen within $4 \mathrm{~h}$ of collection. Several days after freezing, the frozen sagebrush was ground with a chipper (Craftsman chipper/shredder, 
model No. 987.799930, Sears, Salt Lake City, UT) to 1 to $2 \mathrm{~cm}$ in length, mixed for uniformity, placed in plastic bags in 5-kg amounts, and returned to a freezer. Every day during the experiment, bags of sagebrush were removed from the freezer, thawed, and fed.

After the lambs received the diets without terpenes for $6 \mathrm{~d}$, we determined the influence of sagebrush on intake and preference for isoenergetic and isonitrogenous diets with different proportions of beet pulp and barley grain. Lambs remained in the same groups and received the same diets.

At 0800 each morning, the lambs received $1 \mathrm{~kg}$ of the beet-pulp-based diet (group 1), $1 \mathrm{~kg}$ of the barley-grainbased diet (group 2), or a choice of $1 \mathrm{~kg}$ of each diet (group 3) for $10 \mathrm{~min}$. Intake of the diets was recorded. After receiving their respective diets, all lambs had ad libitum access to big sagebrush for $3 \mathrm{~h}$. Refusals were collected, and intake was calculated. Immediately after collecting the sagebrush, all lambs were again offered the diets, as described above, for $45 \mathrm{~min}$. Intake of the diets was measured, and no other feed was offered until the next day. The procedure was repeated for $14 \mathrm{~d}$. The first $4 \mathrm{~d}$ were used to familiarize the lambs with the procedures and feed ingredients, and data were recorded during the following $10 \mathrm{~d}$. Lambs weighed $40 \pm$ $1.1 \mathrm{~kg}$ after exposure to the diets and sagebrush.

\section{In Vivo Digestion Trial}

Eight commercial crossbred wethers (4 to 5 mo of age; $35 \pm 1.2 \mathrm{~kg}$ of initial BW were stratified by BW and assigned to 2 groups (4 lambs/group). Lambs were housed in metabolic crates under a protective roof and had free access to trace mineral salt blocks and fresh water throughout the study.

During period 1 , lambs in group 1 were offered the beet pulp-based diet and lambs in group 2 were offered the barley grain-based diet (Table 1). Procedures in period 2 were the same as those in period 1 , but terpenes were added to the diets (Table 1). This sequence was used rather than a crossover design to avoid carryover effects due to ingestion of toxins (terpenes), which may have caused aversions that lingered in subsequent periods. Experimental periods were $17 \mathrm{~d}$ in length. Within each period, the first $10 \mathrm{~d}$ were used for adaptation to diets, and the last $7 \mathrm{~d}$ were used for sample collection. Lambs were exercised for $6 \mathrm{~d}$ between experimental periods. While exercising, groups were maintained in individual pens, and they continued to receive their respective beet pulp- and barley grain-based diets without terpenes.

Diets were offered at $110 \%$ of ad libitum intake at 0800, and additional food was added at 1900 when refusals were below $10 \%$ of the amount initially offered. Diets were weighed individually for each lamb based on the previous day's consumption. Refusals from each lamb were collected before 0800 and weighed. Total feces voided in 24-h cycles were collected for each lamb and weighed. Representative (20\% of the amount re- trieved) daily samples of feed, orts, and feces from each lamb were taken daily during the 7-d sampling period, dried at $60^{\circ} \mathrm{C}$ in a forced-air oven, and ground through a Wiley mill (1-mm screen). Samples were weighed immediately before and after drying. Orts and feces were composited for each lamb within period, where each sample contributed to the composite in quantities proportional to the amount of food refused or to the amount of feces excreted (DM basis) during the day the sample was taken.

Diets for each sampling day, and composited orts and feces, were analyzed for DM (AOAC, 1990), NDF, ADF (Goering and Van Soest, 1970), and hemicellulose (NDF-ADF). Diets were also analyzed for $\mathrm{N}$ by using the Kjeldahl procedure (AOAC, 1990). Data were used to calculate the apparent in vivo digestibility of DM, $\mathrm{NDF}, \mathrm{ADF}$, and hemicellulose.

During the last day of each sampling period, ruminal fluid was collected with a stomach tube and a vacuum pump at 0 (immediately before feeding), 2, 4, 6, and 8 $\mathrm{h}$ after feeding. Ruminal fluid was strained through 4 layers of cheesecloth, and its $\mathrm{pH}$ was immediately measured ( $\mathrm{pH}$ meter No. 44, Beckman Instruments, Palo Alto, CA). Samples of $16 \mathrm{~mL}$ were added to vials containing $4 \mathrm{~mL}$ of $25 \%$ (wt/vol) metaphosphoric acid and stored at $-20^{\circ} \mathrm{C}$ before analyses for VFA and lactic acid. Before analyses, samples were centrifuged at $20,000 \times g$ for $20 \mathrm{~min}$.

Concentrations of VFA were determined using a gas chromatograph (model 14A, Shimadzu America Inc., Columbia, MD) on a glass column (i.d. $170 \mathrm{~cm} \times 2.6$ $\mathrm{mm}$ ) packed with $10 \%$ SP-1200 (phase A)/1\% H3PO4 (phase B) on a mesh size 80/100 with support Chromosorb W-AW (Supelco Inc., Bellefonte, PA). Nitrogen was used as a carrier gas at $150 \mathrm{kPa}$. The oven temperature was $125^{\circ} \mathrm{C}$, and the detector, injector, and column temperature was $100^{\circ} \mathrm{C}$. Lactic acid ( $\mathrm{L}$ form) was determined by injecting a 1:4 dilution of the sample:distilled water into a YSI 2700 Select Biochemistry Analyzer (YSI Inc., Yellow Springs, OH), which provided a direct reading at the enzyme sensor, where L-lactate is oxidized to pyruvate and water is converted to peroxide in the enzymatic reaction catalyzed by L-lactate oxidase.

\section{Statistical Analyses}

Analyses were conducted using the MIXED procedure of SAS (SAS Inst. Inc., Cary, NC; Version 9.1 for Windows). When $F$ values were significant $(P<0.10)$, means were compared using the LSD test.

Influence of Terpenes and Sagebrush on Intake and Preference for Diets of Different Composition. The statistical design for the ANOVA was a split-plot with lambs nested within group (1,2, and 3). Group was the whole-plot factor, and day was the subplot factor. To determine whether intake for the terpene-containing diets changed when terpenes were absent from the diets, period ( $1=$ without terpenes; $2=$ with terpenes) was included in the analysis of the first experiment as 
a subplot factor. When lambs had a choice between diets (group 3), lambs and diets were the whole-plot factors and day was the subplot. The dependent variables were intake and preference [(intake of test diet/ total intake) $\times 100$ ]. For analysis, intake was converted to grams of food ingested/kg of metabolic BW $\left(\mathrm{kg}^{0.75}\right)$.

In Vivo Digestion Trial. Apparent in vivo digestibility of DM, NDF, ADF, and hemicellulose, and values for $\mathrm{pH}$, lactic acid, and VFA concentrations were analyzed in a split-plot design with lambs nested within group ( 1 = beet pulp-based diet; 2 = barley grain-based diet). Group was the whole plot factor and period ( $1=$ without terpenes, $2=$ with terpenes) and day (digestibility estimations during $7 \mathrm{~d}$ ) or time of rumen fluid extraction $(0,2,4,6$, and $8 \mathrm{~h})$ were the subplot factors.

\section{RESULTS}

\section{Ingestion of Test Diets with and Without Terpenes}

Intake of the beet-pulp-based diet (group 1) was the greatest (when compared with groups 2 and 3 ) on $d 1$ to 10 , before terpenes were added to the diets (period $1 ; P<0.05$; Figure 1a). Averaged across d 1 to 10 , lambs in groups 1 (beet pulp), 2 (grain), and 3 (choice) consumed, respectively, 77, 66, and $70 \mathrm{~g} / \mathrm{kg}^{0.75}$ (SEM = 3.7). Addition of terpenes to the diets on d 11 to 20 depressed intake in groups 1 [from $77 \mathrm{~g} / \mathrm{kg}^{0.75}$ (d 1 to 10) to $50 \mathrm{~g} / \mathrm{kg}^{0.75}$ (d 11 to 20)] and 3 [from $70 \mathrm{~g} / \mathrm{kg}^{0.75}$ (d 1 to 10 ) to $58 \mathrm{~g} / \mathrm{kg}^{0.75}$ (d 11 to 20 ); $P<0.001$; Figure 1a], but not in group 2 [66 (d 1 to 10$)$ vs. $62(\mathrm{~d} 11$ to 20$) \mathrm{g} /$ $\left.\mathrm{kg}^{0.75} ; P=0.16\right]$. When terpenes were present in the diets, lambs in groups 2 (barley $62 \mathrm{~g} / \mathrm{kg}^{0.75}$ ) and 3 (choice $58 \mathrm{~g} / \mathrm{kg}^{0.75}$ ) ate more than lambs in group 1 (beet pulp $50 \mathrm{~g} / \mathrm{kg}^{0.75} ; P<0.05 ; \mathrm{SEM}=3.7$; Figure 1a), which caused a group $\times$ period interaction $(P=0.009)$. When terpenes were removed from the diets (d 21 to 26 ), intake did not differ among groups $(P>0.20$; Figure 1a).

Addition of terpenes changed preference for the test diets in group 3. Without terpenes, lambs ate more (40 vs. $31 \mathrm{~g} / \mathrm{kg}^{0.75}$; SEM = 4.7) and preferred (57 vs. $43 \%$; $\mathrm{SEM}=6.6$ ) the barley- to the beet pulp-based diet, but their patterns of food intake ( 26 vs. $32 \mathrm{~g} / \mathrm{kg}^{0.75}$; SEM = 4.7 ) and preference ( 45 vs. $55 \%$; SEM $=6.6$ ) reversed when terpenes were added to the diets, which caused a diet $\times$ period interaction for intake $(P=0.09)$ and for preference $(P=0.04$; Figures $1 \mathrm{~b}$ and $2 \mathrm{a})$. When terpenes were removed, intake $(P=0.088)$ and preference $(P=$ 0.069 ) were greater once again for the barley- than for the beet pulp-based diet (Figures $1 \mathrm{~b}$ and $2 \mathrm{a}$ ).

\section{Ingestion of Test Diets and Sagebrush}

Intake of the beet pulp- and barley-based diets did not differ among groups before lambs ate a meal of sagebrush (group effect; $P=0.78$ ). However, after eating sagebrush, lambs in group 2 (barley) ate less than lambs in group 1 (beet pulp) or group 3 (choice; group effect; $P=0.07$; group $\times$ day; $P=0.07$; Figure $3 a$ ). Averaged across days, lambs in groups 1 and 3 ate, respectively, $54 \mathrm{~g} / \mathrm{kg}^{0.75}$ of the beet pulp-based diet and $56 \mathrm{~g} / \mathrm{kg}^{0.75}$ of a choice of both diets, whereas lambs in group 2 ate $49 \mathrm{~g} / \mathrm{kg}^{0.75}$ of the barley-based diet (SEM = 2.0). Intake of sagebrush did not differ among groups (groups 1,2 , and 3 ate $8.2,9.7$, and $7.5 \mathrm{~g} / \mathrm{kg}^{0.75}$, respectively; $\mathrm{SEM}=0.87$; group effect, $P=0.21$; group $\times$ day interaction, $P=0.84$ ).

When lambs were offered a choice (group 3), intake $(P=0.23)$ and preference $(P=0.20)$ did not differ between the beet-pulp- and barley-based diets before eating sagebrush. After eating sagebrush, lambs ate more (34 vs. $23 \mathrm{~g} / \mathrm{kg}^{0.75} ; \mathrm{SEM}=2.8 ; P=0.02$ ) and preferred ( 60 vs. $40 \%$; SEM $=4.7 ; P=0.008$ ) the beet pulpbased diet to the barley-based diet (Figures $2 \mathrm{~b}$ and $3 \mathrm{~b}$ ).

\section{In Vivo Digestion Trial}

Digestibility. In vivo digestibility of DM $(P=0.009)$, NDF $(P<0.001), \operatorname{ADF}(P=0.001)$, and hemicellulose $(P=0.001)$ were all greater for the beet pulp- than for the barley-based diet with or without terpenes (Table 2 ). The addition of terpenes to both diets led to similar (period $\times$ diet interactions; $P>0.53$ ) increases in digestibility of DM $(P=0.04), \operatorname{NDF}(P=0.01)$, and $\operatorname{ADF}(P=$ 0.002 ; Table 2). Intake of the 2 diets without terpenes during period 1 (beet pulp $111 \pm 7 \mathrm{~g} / \mathrm{kg}^{0.75}$; barley $91 \pm$ $8 \mathrm{~g} / \mathrm{kg}^{0.75}$ ) did not change with the addition of terpenes during period 2 (beet pulp $114 \pm 7 \mathrm{~g} / \mathrm{kg}^{0.75}$; barley 114 $\pm 8 \mathrm{~g} / \mathrm{kg}^{0.75}$; group $\times$ period interaction; $P=0.20$ ).

Terpenes increased rumen $\mathrm{pH}$ of lambs fed the barley-based diet but not of lambs fed the beet pulp-based $\operatorname{diet}($ period $\times \operatorname{diet}$ interaction; $P=0.02$; Table 2 ). The increase in $\mathrm{pH}$ was likely due to lower concentrations of total VFA $(P=0.004)$, and a tendency to lower concentrations of L-lactic acid $(P=0.22)$ with the addition of terpenes to the diets (Table 2). Concentrations of Llactic acid tended to be lower in the beet pulp- than in the barley-based diet $(P=0.18$; Table 2$)$.

Concentrations of VFA were affected differently by the addition of terpenes. Acetate was greater for the beet pulp- than for the barley-based diet with or without terpenes $(P=0.07)$, and terpenes depressed acetate production for both diets $(P=0.0017$; Table 2$)$. Without terpenes, acetate concentration peaked at $2 \mathrm{~h}(79.8$ $\mathrm{mM})$ and at $4 \mathrm{~h}(57.7 \mathrm{mM})$ for the beet pulp and barleybased diets, respectively. With terpenes, peaks were delayed to $6 \mathrm{~h}$ (beet pulp: $69.2 \mathrm{~m} M$; barley: $39.4 \mathrm{mM}$; period $\times \operatorname{diet} \times$ time interaction; $P=0.001$; Figure 4 ). Terpenes also decreased concentrations of butyrate in the barley- but not in the beet pulp-based diet (period $\times$ diet interaction; $P=0.08$; Table 2 ).

Propionate concentrations were greater in the barleythan in the beet pulp-based diet $(P=0.006$; Table 2$)$. Its concentrations, and those of all other VFA measured, were not affected by terpenes (period, period $\times$ diet, period $\times \operatorname{diet} \times$ time interactions; $P=0.14$ to 0.86 ; Table 2). 

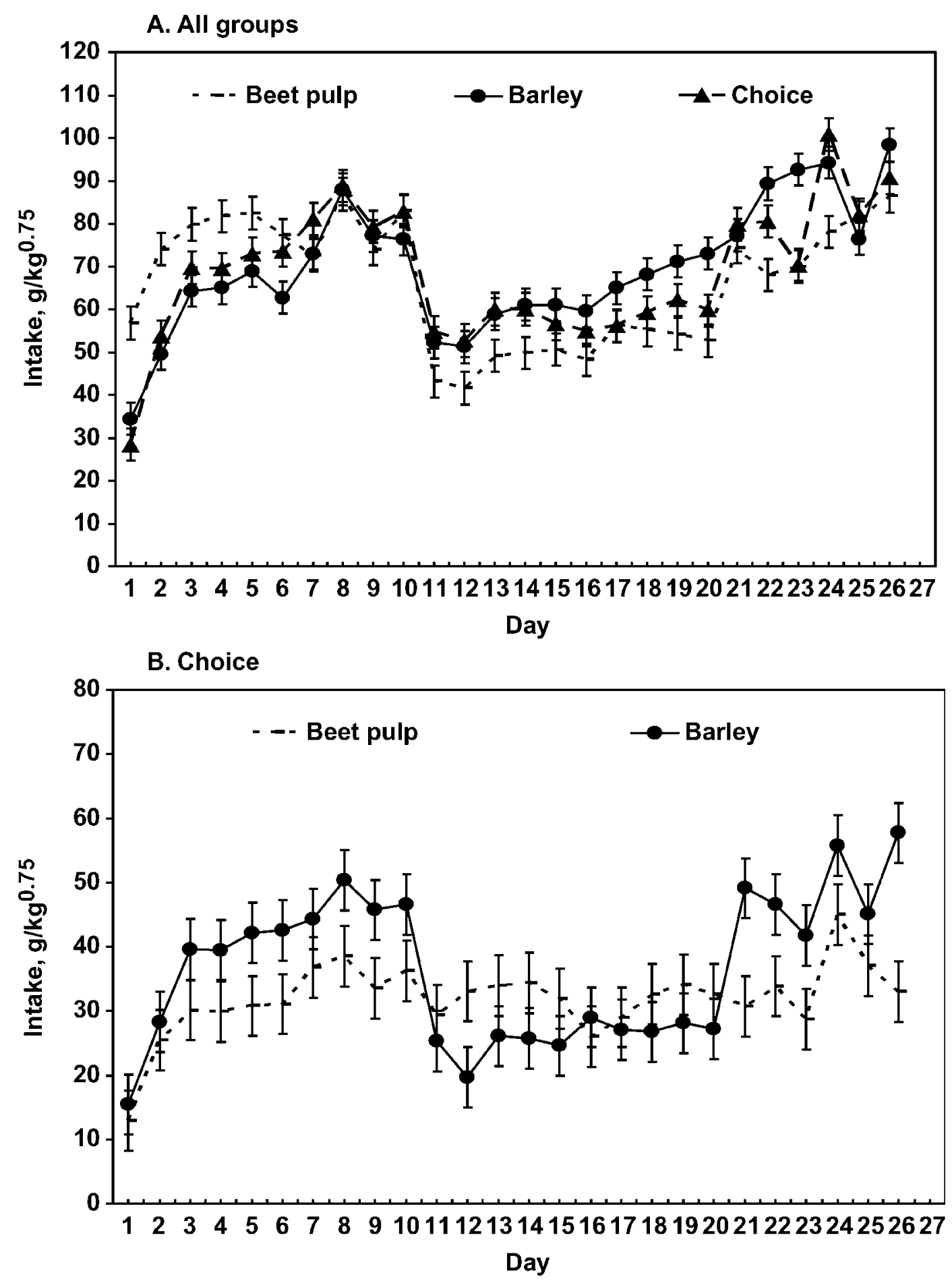

Figure 1. Intake of 2 isonitrogenous and isoenergetic diets by 3 groups of lambs. Lambs were given a beet pulpbased diet (Beet pulp), a barley-based diet (Barley), or a choice between the 2 diets (Choice; panel A). Intake displayed by the group offered a choice of the 2 diets (panel B). From d 1 to 10, lambs received their respective diets without terpenes. From d 11 to 20, terpenes were added to the diets at the same relative concentrations found in sagebrush. From d 21 to 26, terpenes were removed from the diets. Values are means for 8 lambs/group; SE are represented by vertical bars.

Without terpenes, total VFA concentrations were greater for the beet pulp- than for the barley-based diet at $2 \mathrm{~h}(132$ vs. $99 \mathrm{mM})$, but the pattern reversed at 4 h (106 vs. $127 \mathrm{mM})$ and at $6 \mathrm{~h}(84$ vs. $127 \mathrm{mM})$. When terpenes were added to the diets, total VFA concentrations were greater for the beet pulp than for the barleybased diet at $6 \mathrm{~h}(118$ vs. $94 \mathrm{mM}$; period $\times \operatorname{diet} \times$ time interaction; $P=0.002$; Figure 4$)$. 

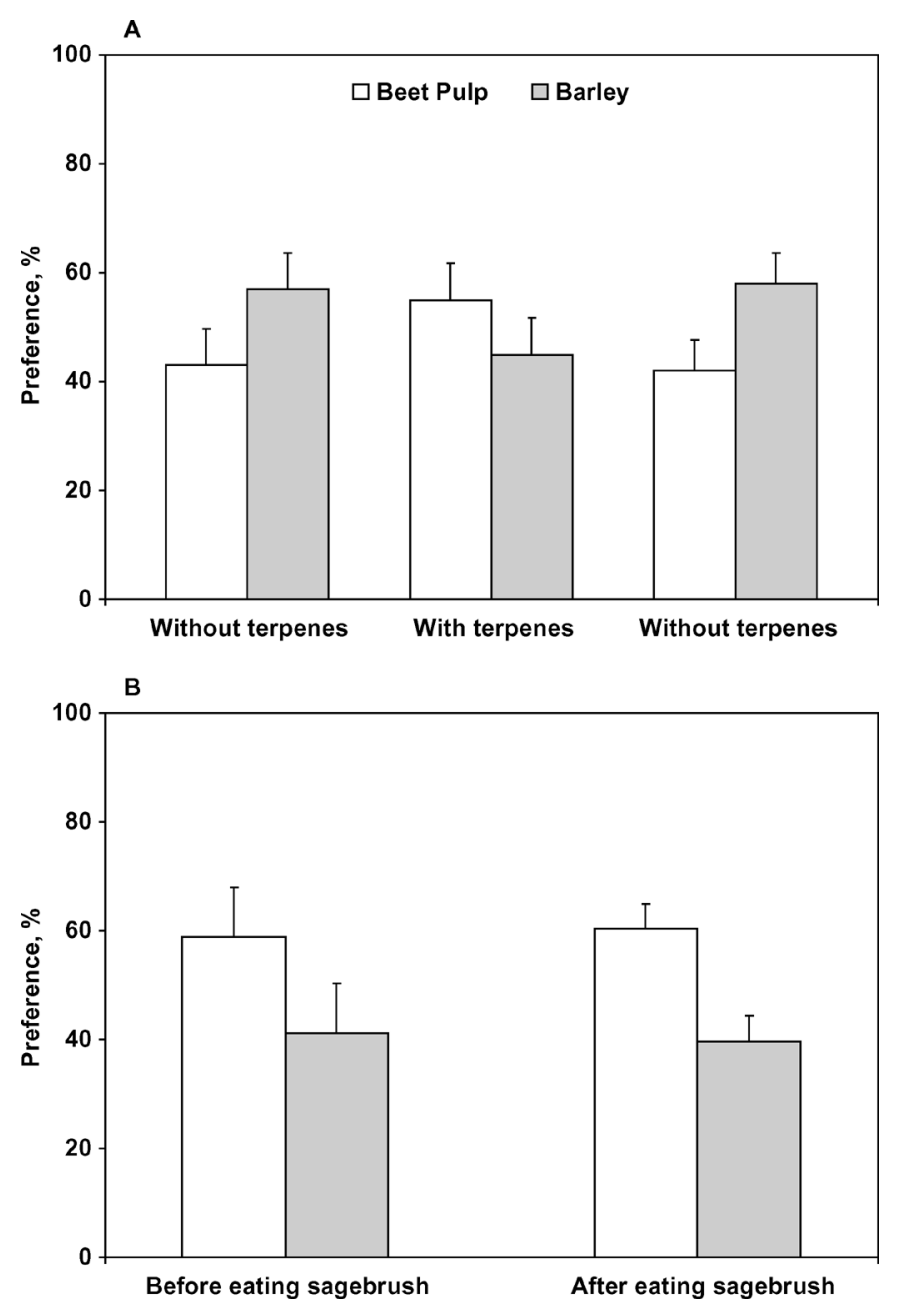

Figure 2. Preference in lambs for a beet pulp- (Beet pulp) and a barley-based diet (Barley) when both diets were offered simultaneously. From d 1 to 10, lambs received their respective diets without the addition of terpenes (Without terpenes). From d 11 to 20, terpenes were added to the diets at the same relative concentrations found in sagebrush (With terpenes). From d 21 to 26, terpenes were removed from the diets (Without terpenes; panel A). In a second trial, lambs received the beet pulpand barley-based diets without terpenes for $10 \mathrm{~min}$ before and for $45 \mathrm{~min}$ after being offered sagebrush during a period of $3 \mathrm{~h}$ (panel B). Values are means for 8 lambs; SE are represented by vertical bars.

\section{DISCUSSION}

\section{Influence of Terpenes on Food Intake, Digestibility, and Ruminal Parameters}

Intake of the beet pulp-based diet was most affected by the addition of terpenes (Figure 1a). The decrease in acetate concentration, the VFA produced in a greater proportion with this diet, reduced the supply of energy to the host, which likely reduced lambs' ability to detoxify and eliminate terpenes (Illius and Jessop, 1995, 1996). The energetic consequences of processing ter- penes by mammalian herbivores can be considerable. For instance, intake of terpenes in juniper by woodrats increased the energy excreted in urine and feces, which compromised energy expenditure and increased energy needed to tolerate further intake of toxins (Sorensen et al., 2005).

Food intake is inversely related with concentration of terpenes in the diet, and sheep are unable to consume terpenes above a threshold (Dziba and Provenza, 2006; Dziba et al., 2006). However, the type and amount of a nutrient(s) ingested influences the degree at which plant toxin(s) may suppress intake (Villalba et al., 2002a). Terpenes must be transformed from lipophilic to hydrophilic compounds before excretion (Cheeke and Schull, 1985). These transformations deplete the body of AA and glucose (Illius and Jessop, 1995, 1996), suggesting that appropriate amounts of nutrients should increase the threshold of toxin tolerance and allow animals to increase their intake of toxin-containing foods. Sheep offered terpene-containing foods with increasing concentrations of energy or protein increase consumption of terpenes in a graded fashion directly related with energy and protein availability (Villalba and Provenza, 2005). Collectively, this suggests that the lower the inhibition of ruminal fermentation by terpenes, the more energy (VFA) will be available to sustain terpene intake.

In contrast to acetate, concentrations of propionate, the VFA produced in greater proportions by lambs fed the grain-based diet, were not affected by terpenes (Table 2; Figure 4). Moreover, the addition of terpenes increased rumen $\mathrm{pH}$ for the barley-based diet, likely in response to the lower concentrations of VFA and Llactic acid (Table 2). Even with selective depression of butyrate, the unchanged supply of propionate and greater $\mathrm{pH}$ likely sustained intake in lambs when terpenes were added to the grain-based diet (Figure 1a). Because propionate is the most important glucogenic VFA, adequate amounts of propionate are crucial for the ruminant's ability to tolerate toxins (terpenes) because glucose is required as a substrate for detoxification processes (Illius and Jessop, 1995). Moreover, adequate amounts of propionate spare glucogenic AA, and consequently protein, for the synthesis of glucose.

Terpenes have bacteriostatic and bactericidal properties (Oh et al., 1970; Nagy and Regelin, 1977). Terpenoid extracts of sagebrush inhibit rumen microorganisms and decrease the rate of cellulose digestion and the production of VFA. Concentrations of 0.04 and 0.08 $\mathrm{mL}$ of terpenoids $/ 10 \mathrm{~mL}$ of ruminal fluid depressed VFA production from a sagebrush substrate by 41 and $48 \%$ after $2 \mathrm{~h}$, and by 20 and $41 \%$ after $4 \mathrm{~h}$ (Nagy et al., 1964). Terpenes in sagebrush have marked antibacterial effects in the rumen of wild and captive deer when concentrations reach $0.016 \mathrm{~mL} / 10 \mathrm{~mL}$ of rumen fluid (Nagy and Tengerdy, 1968). Likewise, concentrations of sagebrush oils of $0.01 \mathrm{~mL} / 10 \mathrm{~mL}$ of ruminal fluid decrease the rate of cellulose digestion, with complete suppression at concentrations of $0.07 \mathrm{~mL} / 10 \mathrm{~mL}$ (Nagy 

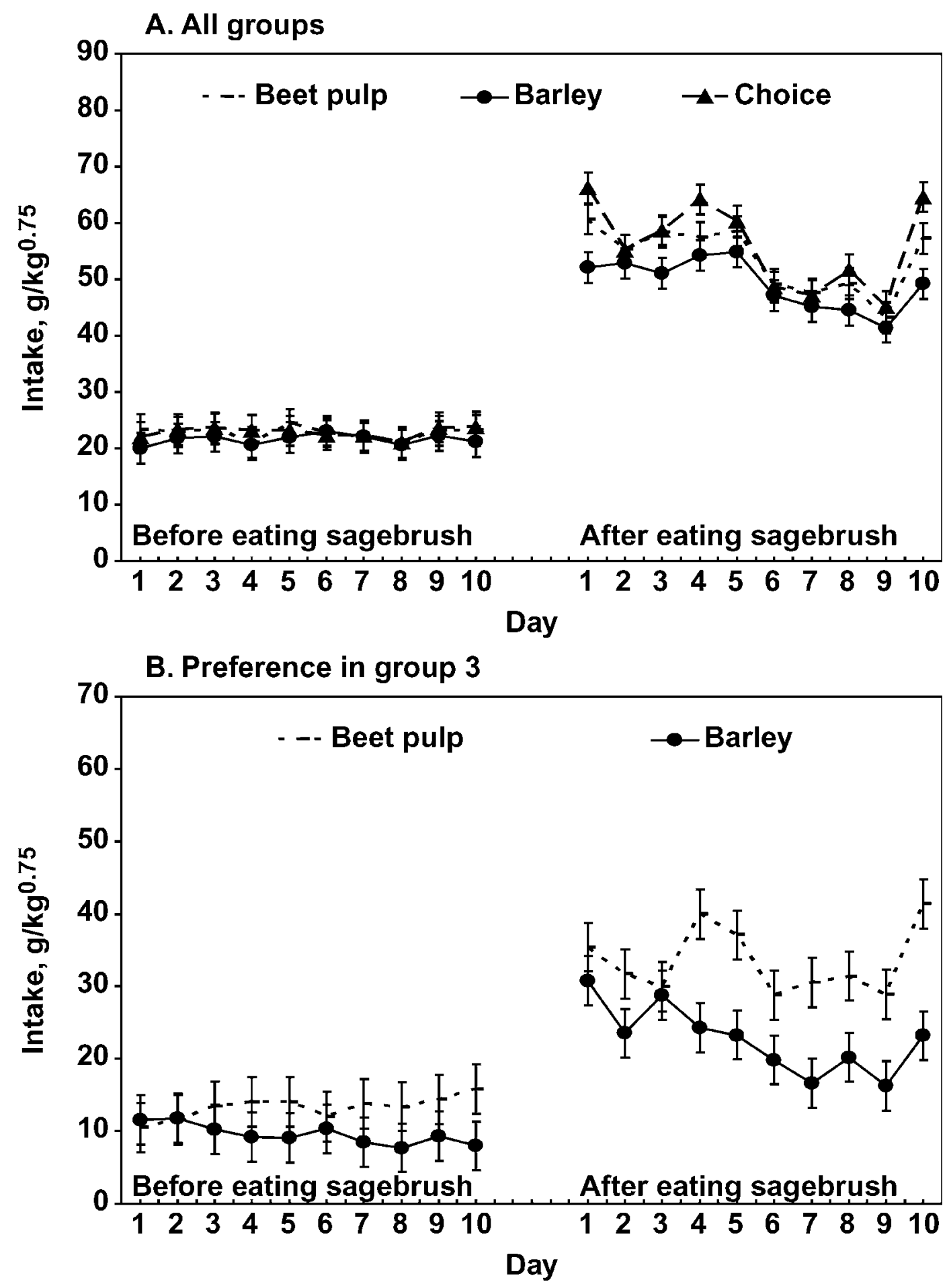

Figure 3. Intake of 2 isonitrogenous and isoenergetic diets by 3 groups of lambs. Lambs were given a beet pulpbased diet (Beet pulp), a barley-based diet (Barley), or a choice between the 2 diets (Choice) for 10 min before and for $45 \mathrm{~min}$ after being offered sagebrush during a period of $3 \mathrm{~h}$ (panel A). Intake displayed by the group offered a choice of the 2 diets (panel B). Values are means for 8 lambs/group; SE are represented by vertical bars.

and Tengerdy, 1968). These studies, conducted in vitro, are consistent with our results in vivo that show terpenes depressed total VFA production in both diets (Table 2). Nevertheless, the depression due to terpenes depended on the type of VFA (acetate was depressed whereas propionate was not) and diet (butyrate was depressed in the barley-based diet but not in the beet pulp-based diet) (Table 2). Apparently, the metabolism of oxalacetate to succinate, the main route used by rumen organisms to synthesize propionate, was not significantly affected by terpenes. Conversely, the pathway leading to the formation of acetate from pyruvate, 
Table 2. Apparent digestibility and ruminal characteristics of 2 groups of lambs consuming beet pulp- and barley-based diets with or without added terpenes

\begin{tabular}{|c|c|c|c|c|c|}
\hline \multirow[b]{2}{*}{ Item } & \multicolumn{2}{|c|}{ Without terpenes } & \multicolumn{2}{|c|}{ With terpenes } & \multirow[b]{2}{*}{ SEM } \\
\hline & Beet pulp & Barley & Beet pulp & Barley & \\
\hline \multicolumn{6}{|l|}{ Digestibility, \% } \\
\hline DM & $75.3^{\mathrm{a}}$ & $69.7^{\mathrm{b}}$ & $77.8^{\mathrm{c}}$ & $73.7^{\mathrm{ad}}$ & 1.24 \\
\hline $\mathrm{NDF}$ & $70.0^{\mathrm{a}}$ & $36.7^{\mathrm{b}}$ & $75.5^{\mathrm{c}}$ & $42.8^{\mathrm{d}}$ & 2.29 \\
\hline $\mathrm{ADF}$ & $62.3^{\mathrm{a}}$ & $24.0^{\mathrm{b}}$ & $71.1^{\mathrm{c}}$ & $32.7^{\mathrm{d}}$ & 3.70 \\
\hline Hemicellulose & $84.1^{\mathrm{a}}$ & $60.3^{\mathrm{b}}$ & $82.8^{\mathrm{a}}$ & $54.8^{\mathrm{b}}$ & 3.80 \\
\hline \multicolumn{6}{|l|}{ Ruminal variables } \\
\hline $\mathrm{pH}$ & $6.4^{\mathrm{a}}$ & $5.9^{\mathrm{b}}$ & $6.3^{\mathrm{a}}$ & $6.2^{\mathrm{a}}$ & 0.16 \\
\hline L-Lactate, $\mathrm{m} M$ & 0.09 & 0.30 & 0.05 & 0.11 & 0.08 \\
\hline \multicolumn{6}{|l|}{ VFA, $m M$} \\
\hline Acetate & $62.6^{\mathrm{a}}$ & $48.6^{\mathrm{b}}$ & $45.1^{\mathrm{bc}}$ & $31.9^{\mathrm{d}}$ & 4.87 \\
\hline Propionate & $28.0^{\mathrm{a}}$ & $42.4^{\mathrm{b}}$ & $22.4^{\mathrm{a}}$ & $40.8^{\mathrm{b}}$ & 3.94 \\
\hline Butyrate & $10.7^{\mathrm{a}}$ & $9.2^{\mathrm{a}}$ & $10.5^{\mathrm{a}}$ & $4.6^{\mathrm{b}}$ & 1.50 \\
\hline Isobutyrate & 0.4 & 0.5 & 0.4 & 0.5 & 0.07 \\
\hline Valerate & 1.6 & 2.6 & 1.3 & 2.0 & 0.49 \\
\hline Isovalerate & 0.1 & 2.0 & 0.3 & 0.5 & 0.91 \\
\hline Total & $102.5^{\mathrm{a}}$ & $105.2^{\mathrm{a}}$ & $80.0^{\mathrm{b}}$ & $80.4^{\mathrm{b}}$ & 8.40 \\
\hline
\end{tabular}

${ }^{\mathrm{a}-\mathrm{d}}$ Means within a row lacking a common superscript letter differ $(P<0.05)$.

or proliferation of cellulolytic bacteria through the bacteriostatic actions of terpenes, was affected in both diets. The pathway leading to the condensation of acetyl-CoA into butyrate was affected in the barleybased diet.

Whereas previous studies have only considered the effects of terpenes on structural carbohydrate-based diets, our study also addresses the effects of terpenes on the fermentation response of nonstructural carbohydrates. In contrast to previous findings that suggest sagebrush inhibits in vivo DM digestibility (Ngugi et al., 1995), the addition of terpenes to both diets in our study caused increases in the digestibility of DM, NDF, and $\mathrm{ADF}$ (Table 2). Digestibility depression is a function of the competition between rates of digestion and passage (Van Soest, 1994). Terpenes in our study apparently increased ruminal retention times, which increased extent of digestion. Nevertheless, greater digestibilities in the presence of terpenes were associated with a decline, rather than an increase, in the concentration of fermentation products (Table 2). Digestibility of DM and fiber was greater for the beet pulp- than for the barley-based diet with or without terpenes. Starch in grain inhibits fiber digestion by depressing rumen $\mathrm{pH}$ or through competition with starch as a substrate (El-Shazly et al., 1961; Van Soest, 1994).

Though several studies have explored effects of terpenoids on sagebrush digestion, little attention has been given to the chemical composition and degradability of different plant parts of sagebrush (leaves, current growth twigs, older growth twigs, seeds) and forages other than sagebrush that could be affected by terpenes. The differential action of terpenes on intake and digestion of sagebrush and other forages is particularly important when considering that chemical composition may vary substantially among and within plant species and tissue types (Dearing and Schall, 1992). Sagebrush might inhibit digestion and intake of grasses, forbs, and supplements. Extracts of some accessions of big sagebrush severely inhibit in vitro cell wall digestibility of grasses (Hobbs et al., 1986) and our study shows terpenes depressed intake of the beet pulp-based diet but not of the barley-based diet (Figure 1a).

Ingestion of supplements in large amounts can substitute for use of forages (Caton and Dhuyvetter, 1997). Ingestion of grain-based supplements by sheep and goats increased the likelihood of an animal substituting grain for sagebrush (Villalba et al., 2002a). In our study, intake of sagebrush was not affected by type of diet (nonstructural or structural based diets) ingested before or after lambs consumed sagebrush. However, intake of fall-harvested sagebrush in our study was low, from 7.5 to $9.7 \mathrm{~g} / \mathrm{kg}^{0.75}$, which is consistent with the fact that as concentrations of terpenes in sagebrush increase in the fall, intake and preference decrease (Welch, 1983). When sheep consume greater amounts of spring-harvested sagebrush (50 g/ $\left.\mathrm{kg}^{0.75}\right)$, grain supplements depress intake of sagebrush by $38 \%$ relative to a protein-based supplement (Villalba et al., 2002a).

\section{Influence of Terpenes on Preference}

Lambs always ate both the grain- and beet pulpbased diets, but their preference for each depended on terpenes. Without terpenes in the diets, lambs preferred the grain-based diet. This response can be interpreted through the ruminal ratios of propionate:acetate produced by the 2 diets. Preference for flavors associated with intraruminal infusions of isoenergetic combinations of acetate and propionate in lambs increased as the proportion of propionate:acetate increased in the infusions (Villalba and Provenza, 1997). The grain- 

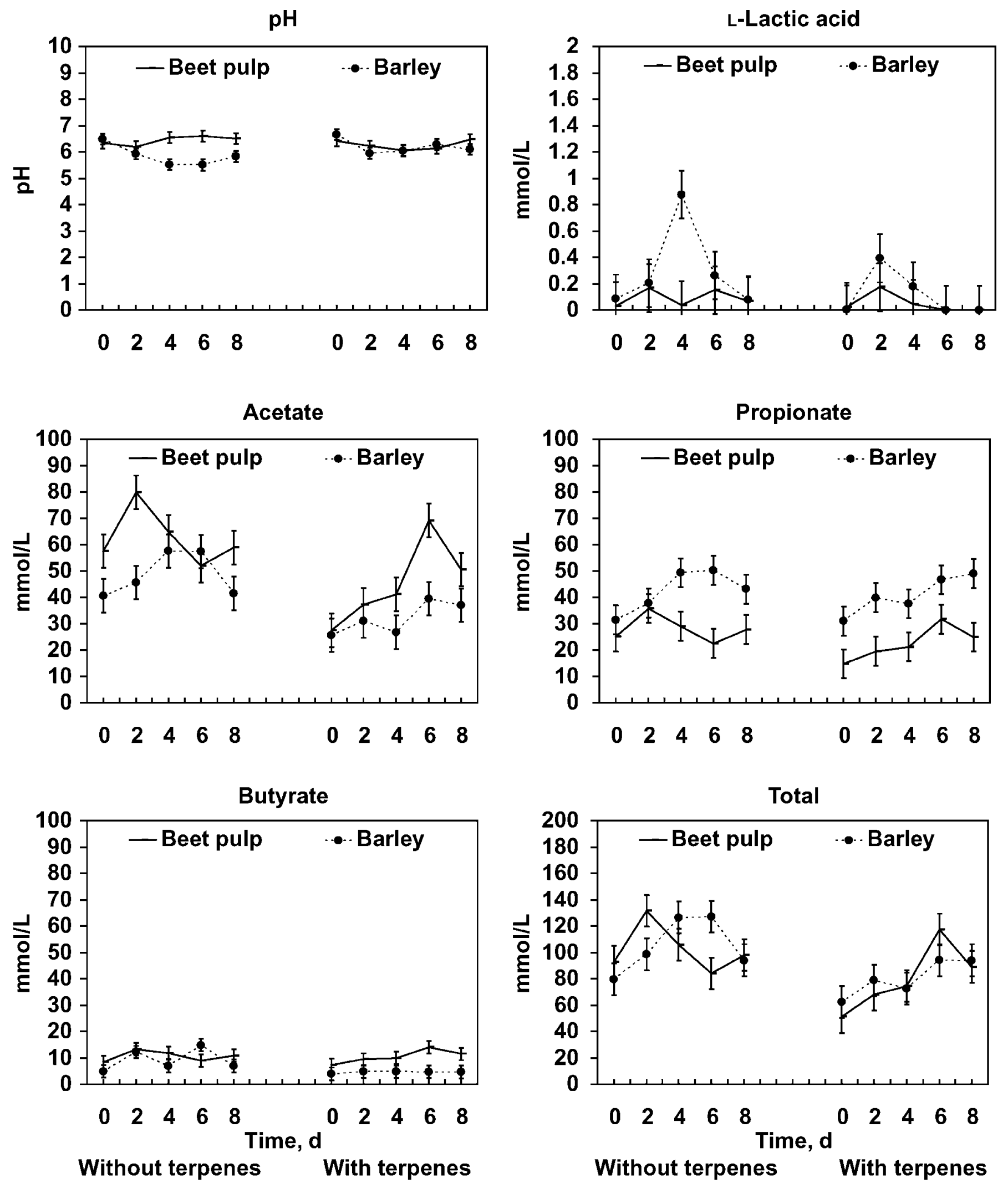

Figure 4. Ruminal characteristics of 2 groups of lambs consuming beet pulp- (Beet pulp) and barley-based (Barley) diets. Lambs received the diets in 2 periods. During period 1, lambs received their respective diets without terpenes. During period 2, terpenes were added to the diets at the same relative concentrations found in sagebrush. Values are means for 4 lambs/group; SE are represented by vertical bars. 
based diet produced a greater ratio of propionate:acetate (Table 2), which likely induced a greater preference for this diet. However, preference reversed when terpenes were added to the diets or after lambs ate sagebrush (Figures $2 a, b$ and $3 b$ ). Lambs offered the grainbased diet tended to eat the least amounts of food after eating sagebrush (Figure 3a), supporting the notion of a negative interaction between terpenes and preference for grain-based diets (Villalba et al., 2002a,b). Addition of terpenes to the barley-based diet decreased production of butyrate (Table 2), and total VFA concentration was lower for the barley- than for the beet pulp-based diet at $6 \mathrm{~h}$ (Figure 4), which may have lowered preference for the barley-based diet.

Sheep preferred the beet pulp-based diet when both diets contained terpenes (Figure 1b), but the grainbased diet still constituted approximately $40 \%$ of the diet. A starch-based supplement provides a greater proportion of glucogenic precursors (propionate) needed for terpene detoxification, thus reducing the negative effects of terpenes on the animal and potentially on fiber fermentation.

Collectively, these results indicate lambs benefited from eating grain- and fiber-based sources of energy. A variety of carbohydrate sources (cellulose, hemicellulose, starch) may enhance tolerance of toxins, as shown by lambs offered a choice relative to lambs offered only the beet-pulp based food (Figure 1a). Lambs fed both diets simultaneously ate amounts of terpenes comparable to lambs fed the barley-based diet. Thus, a choice enhanced intake of terpenes and enabled more balanced use of grain and beet pulp. When animals eat a variety of feeds containing different toxins, they ingest more nutrients because single feeds with toxins saturate detoxification pathways and thus constrain feed intake (Freeland and Janzen, 1974). Animals given a choice of feeds containing different toxins eat more feed than animals given only 1 feed (Dearing and Cork, 1999; Burritt and Provenza, 2000). Thus, biochemical diversity is critical for ingesting both nutrients and toxins (Provenza et al., 2003).

In summary, the type of carbohydrate (structural, nonstructural) influenced fermentation products, digestibility, intake and preference in lambs for feeds with terpenes. Sheep ate more barley- than beet pulpbased diets and propionate concentrations were not inhibited by addition of terpenes to the diets. Thus, grainbased supplements may improve the ability of ruminants to use sagebrush. When offered a choice, lambs always ate both the barley- and beet pulp-based diets, but their preference for each depended on whether they were ingesting terpenes. Lambs fed feeds with terpenes benefited from eating both nonstructural and structural sources of energy, which suggests energy from supplements or other plants is likely to influence intake and preference for sagebrush in sheep foraging on rangelands. Additionally, ingestion of terpenes from sagebrush may influence intake and preference for other plant species or supplements ingested with sagebrush.

\section{LITERATURE CITED}

AOAC. 1990. Official Methods of Analysis. 15th ed. Assoc. Off. Anal. Chem., Arlington, VA.

Burritt, E. A., and F. D. Provenza. 2000. Role of toxins in intake of varied diets by sheep. J. Chem. Ecol. 26:1991-2005.

Caton, J. S., and D. V. Dhuyvetter. 1997. Influence of energy supplementation on grazing ruminants: Requirements and responses. J. Anim. Sci. 75:533-542.

Cheeke, P., and L. R. Shull. 1985. Natural Toxicants in Feeds and Poisonous Plants. Avi Publishing Co., Westport, CT.

Dearing, M. D., and S. Cork. 1999. Role of detoxification of plant secondary compounds on diet breadth in a mammalian herbivore, Trichosurus vulpecula. J. Chem. Ecol. 25:1205-1219.

Dearing, M. D., and J. J. Schall. 1992. Testing models of diet assembly by the generalist herbivorous lizard, Cnemidophorus murinus. Ecology 73:845-867.

Dziba, L. E., and F. D. Provenza. 2006. Sagebrush monoterpenes influence feeding bouts and regulation of food intake by lambs. Appl. Anim. Behav. Sci. In Press.

Dziba L. E., J. O. Hall, and F. D. Provenza. 2006. Feeding behavior of lambs in relation to kinetics of 1,8-cineole dosed intravenously or into the rumen. J. Chem. Ecol. 32:391-408.

El-Shazly, K., B. A. Dehority, and R. R. Johnson. 1961. Effect of starch on the digestion of cellulose in vitro and in vivo by rumen micro-organisms. J. Anim. Sci. 20:268-273.

Freeland, W. J., and D. H. Janzen. 1974. Strategies in herbivory by mammals: The role of plant secondary compounds. Am. Nat. 108:269-289.

Goering, H. K., and P. J. Van Soest. 1970. Forage fiber analyses (apparatus, reagents, procedures, and some applications). Agric. Handbook No. 379. ARS, USDA, Washington, DC.

Hobbs, N. T., B. L. Welch, and T. E. Remington. 1986. Effects of big sagebrush on in vitro digestion of grass cell wall. Pages 186189 in Proc. Symp. Biol. Artemisia and Chrysothamnus. E. D. McArthur, and B. L. Welch, ed. Gen. Tech. Report INT-200, Dept. Agric, Forest Service, Intermountain Research Station, Ogden, UT.

Illius, A. W., and N. S. Jessop. 1995. Modeling metabolic costs of allelochemical ingestion by foraging herbivores. J. Chem. Ecol. 21:693-719.

Illius, A. W., and N. S. Jessop. 1996. Metabolic constraints on voluntary intake in ruminants. J. Anim. Sci. 74:3052-3062.

Nagy, J. G., H. W. Steinhoff, and G. M. Ward. 1964. Effects of essential oils of sagebrush on deer rumen microbial function. J. Wildl. Manage. 28:785-790.

Nagy, J. G., and R. P. Tengerdy. 1968. Antibacterial action of essential oils of Artemisia as an ecological factor. II. Antibacterial action of the volatile oils of Artemisia Tridentata (big sagebrush) on bacteria from the rumen of mule deer. Appl. Microbiol. 16:441-444.

Nagy, J. G., and W. L. Regelin. 1977. Influence of plant volatile oils on food selection by animals. Proc. Congr. Game Biol. 13:225-230.

Ngugi, R. K., F. C. Hinds, and J. Powell. 1995. Mountain big sagebrush browse decreases dry matter intake, digestibility, and nutritive quality of sheep diets. J. Range Manage. 48:487-492.

NRC. 1985. Nutrient Requirements of Sheep. 6th ed. Natl. Acad. Press, Washington, DC.

Oh, J. H., M. B. Jones, W. M. Longhurst, and G. E. Connolly. 1970. Deer browsing and rumen microbial fermentation of Douglasfir as affected by fertilization and growth stage. Forest Sci. 16:21-27.

Personius, T. L., C. L. Wambolt, J. R. Stephens, and R. G. Kelsey. 1987. Crude terpenoid influence on mule deer preference for sagebrush. J. Range Manage. 40:84-88.

Provenza, F. D., J. J. Villalba, L. E. Dziba, S. B. Atwood, and R. E. Banner. 2003. Linking herbivore experience, varied diets, and plant biochemical diversity. Small Rumin. Res. 49:257-274. 
Sorensen, J. S., J. D. McLister, and M. D. Dearing. 2005. Plant secondary metabolites compromise the energy budgets of specialist and generalist mammalian herbivores. Ecology 86:125-139.

Van Soest, P. J. 1994. Nutritional Ecology of the Ruminant. 2nd ed. Cornell Univ. Press, Ithaca, NY.

Villalba, J. J., and F. D. Provenza. 1997. Preference for flavored wheat straw by lambs conditioned with intraruminal infusions of acetate and propionate. J. Anim. Sci. 75:2905-2914.

Villalba, J. J., and F. D. Provenza. 2005. Foraging in chemically diverse environments: Energy, protein and alternative foods influence ingestion of plant secondary metabolites by lambs. J. Chem. Ecol. 31:123-138.
Villalba, J. J., F. D. Provenza, and R. E. Banner. 2002a. Influence of macronutrients and activated charcoal on intake of sagebrush by sheep and goats. J. Anim. Sci. 80:2099-2109.

Villalba, J. J., F. D. Provenza, and J. P. Bryant. 2002b. Consequences of the interaction between nutrients and plant secondary metabolites on herbivore selectivity: Benefits or detriments for plants? Oikos 97:282-292.

Welch, B. L. 1983. Big sagebrush: Nutrition, selection, and controversy. Pages 21-33 in Proc. First Utah Shrub Ecology Workshop, Ephraim, Utah, September 9-10,1981. Kendall L. Johnson, ed. College of Natural Resources, Utah State Univ., Logan.
Downloaded from https://academic.oup.com/jas/article-abstract/84/9/2463/4777933 by guest 